\title{
COVID-19 and Heart Failure: From Epidemiology During the Pandemic to Myocardial Injury, Myocarditis, and Heart Failure Sequelae
}

\section{Leonardo Italia, Daniela Tomasoni, Stefano Bisegna, Edoardo Pancaldi, Lorenzo Stretti, Marianna Adamo and Marco Metra*}

Cardiology, ASST Spedali Civili and Department of Medical and Surgical Specialties, Radiological Sciences and Public Health, University of Brescia, Brescia, Italy

A close and intriguing relationship has been suggested between heart failure (HF) and coronavirus disease 2019 (COVID-19). First, COVID-19 pandemic represented a global public health emergency in the last year and had a catastrophic impact on health systems worldwide. Several studies showed a reduction in HF hospitalizations, ranging from 30
OPEN ACCESS

Edited by:

Hendrik Tevaearai Stahel, Bern University Hospital, Switzerland

Reviewed by:

Kumaravelu Jagavelu, Central Drug Research Institute (CSIR), India Alessandro ladanza

University of Siena, Italy

*Correspondence: Marco Metra metramarco@libero.it

Specialty section:

This article was submitted to General Cardiovascular Medicine,

a section of the journal

Frontiers in Cardiovascular Medicine

Received: 23 May 2021

Accepted: 12 July 2021

Published: 10 August 2021

Citation: Pancaldi E, Stretti L, Adamo M and Metra M (2021) COVID-19 and Heart Failure: From Epidemiology During the Pandemic to Myocardial Injury,

Myocarditis, and Heart Failure Sequelae.

Front. Cardiovasc. Med. 8:713560. doi: 10.3389/fcrm.2021.713560
Italia L, Tomasoni D, Bisegna S, to $66 \%$ in different countries and leading to a subsequent increase in HF mortality. Second, pre-existing HF is a risk factor for a more severe clinical course of COVID-19 and an independent predictor of in-hospital mortality. Third, patients hospitalized for COVID-19 may develop both an acute decompensation of chronic HF and de-novo $\mathrm{HF}$ as a consequence of myocardial injury and cardiovascular (CV) complications. Myocardial injury occurred in at least 10\% of unselected COVID-19 cases and up to $41 \%$ in critically ill patients or in those with concomitant CV comorbidities. Few cases of COVID-19-related acute myocarditis, presenting with severe reduction in the left ventricular (LV) ejection fraction and peculiar histopathological findings, were described. However, recent data suggested that COVID-19 may be associated with both systolic and diastolic LV dysfunction, with LV diastolic impairment, pulmonary hypertension, and right ventricular dysfunction representing the most frequent findings in echocardiographic studies. An overview of available data and the potential mechanisms behind myocardial injury, possibly leading to HF, will be presented in this review. Beyond the acute phase, $\mathrm{HF}$ as a possible long-term consequence of cardiac involvement in COVID-19 patients has been supposed and need to be investigated yet.

Keywords: COVID-19, SARS-CoV-2 infection, heart failure, myocardial injury, epidemiology, myocarditis, pathophysiology

\section{INTRODUCTION}

Coronavirus disease 2019 (COVID-19) rapidly spread around the world becoming a global public health emergency. It is caused by a novel enveloped, positively stranded RNA beta coronavirus named severe acute respiratory syndrome coronavirus 2 (SARS-CoV-2) (1). So far, more than one hundred million of confirmed COVID-19 cases can be counted worldwide, with a total of more than three million deaths, as of June 1, 2021, according to the World Health Organization (2). 
Although COVID-19 was initially considered a respiratory disease, it has rapidly become clear that a multiorgan involvement was common. In particular, the heart often represents a target organ and patients may develop heart failure (HF) (3-6).

Of note, the link between COVID-19 and HF is more complex. First, COVID-19 pandemic has an impact on HF management and a reduction of hospitalizations due to HF has been shown during the pandemic period, possibly leading to an increase in $\mathrm{HF}$ mortality. Second, history of HF is a risk factor for a more severe clinical course of COVID-19. Third, HF can be a consequence of COVID-19-related myocardial damage.

The aim of this review is to describe the epidemiology of HF during the pandemic, the role of cardiac injury and HF in COVID-19, and its pathogenetic mechanisms.

\section{HEART FAILURE EPIDEMIOLOGY DURING COVID-19}

COVID-19 pandemic upsets the epidemiology and the management of acute HF. Urgent cardiovascular (CV) hospital admission showed a general decline during the pandemic period, with also a delay in urgent care and an increased risk of complications $(7,8)$. Similarly, several studies reported a reduction in HF hospitalizations ranging from 30 to $66 \%$ (Table 1) (9-13). An analysis from a tertiary Heart Failure Unit in London showed that the number of HF hospitalizations had a significant decline by $66 \%$ during the COVID-19 pandemic, compared both with a pre-COVID period in the same year and the corresponding time periods from 2017 to 2019 (9). Patients hospitalized for HF during the pandemic were sicker, with higher rates of NYHA class III or IV symptoms and severe peripheral oedema, which are known predictors of poor outcomes in acute HF. The authors speculated that patients with less severe acute HF might have avoided presenting to hospital during the pandemic, due to the fear of acquiring infection (9). Further studies aimed to compare not only the rates of HF hospitalizations but also in-hospital outcomes. Despite similar demographic characteristics, patients admitted with HF in two referral centers in South London in 2020 experienced worse outcomes compared with those admitted in the previous year (12). Hospitalization for HF in 2020 was independently associated with increased mortality risk (12). Similarly, in Germany, there was a decrease by $30 \%$ in urgent HF hospitalizations during the pandemic $(p<0.01)$ with a concomitant higher in-hospital mortality compared with both same-year and previous-year control groups (13).

\section{COVID-19 AND CARDIOVASCULAR COMORBIDITIES}

The clinical presentation and the course of COVID-19 is extremely variable, ranging from an asymptomatic or paucisymptomatic illness, presenting with mild symptoms (e.g., fever, dry cough, and fatigue), to a severe disease [e.g., severe pneumonia and acute respiratory distress syndrome (ARDS)] with possibly fatal outcome (14-18). The earliest reports from China and Italy showed a high prevalence of comorbidities and their association with the severity of COVID-19 and increased mortality (19-21). In a report of 72,314 cases, the overall casefatality rate of COVID-19 was $2.3 \%$, with higher rates in patients with pre-existing comorbidities $[10.5,7.3,6.3$, and $6.0 \%$ in patients with cardiovascular disease (CVD), diabetes, chronic respiratory disease, and hypertension, respectively] (22). A more recent meta-analysis suggested that CVD and cardiovascular risk factors (hypertension and diabetes) were closely related to fatal outcomes in COVID-19 patients, across and independently from all ages (23).

\section{IMPACT OF PRE-EXISTING HEART FAILURE ON COVID-19 CLINICAL COURSE}

Further studies showed that the prevalence of HF as a comorbid condition ranged from 3.3 to $21 \%$ among SARS-CoV-2-infected patients (Table 2) (19-21, 24-28). In a multicenter retrospective study from New York City area, including nearly 3,000 patients with laboratory-confirmed SARS-CoV-2 infection, the prevalence of HF was $10.1 \%$ (25). HF patients were more prone to develop myocardial injury, defined as increased troponin levels. HF history was also found to be associated with an increased risk of hospitalization and a severe clinical course in COVID-19 patients. In a prospective cohort study, among 5,279 people with laboratory confirmed SARS-CoV-2 infection, more than a half were admitted to hospital, of whom 1,904 (69.5\%) were discharged alive (19). Besides age, HF was one of the strongest predictor for in-hospital admission [odds ratio (OR), 4.43; 95\% confidence interval (CI), 2.59-8.04; $p<0.001$ ] and critical illness (OR, 1.9; 95\% CI, 1.4-2.5; $p<0.001$ ) (19). A retrospective analysis conducted in Spain showed that HF was associated with higher risk of mechanical ventilation and mortality among patients hospitalized for COVID-19, regardless of left ventricle ejection fraction (LVEF) (28). Similar results were found in an Italian multicenter study, with HF resulting as an independent predictor of mortality and a risk factor for inhospital complications, namely, acute HF, acute renal failure, and multiorgan failure (27).

\section{THE PATHOPHYSIOLOGY OF COVID-19 MYOCYTE INJURY}

\section{Indirect Mechanisms}

The pathogenesis of myocardial injury in COVID-19 is still not completely clear and likely involves multiple pathways. Overall, myocardial damage can be summarized distinguishing two different mechanisms of injury: the first, "indirect" or "aspecific," common with other severe infections, and the second, "direct" or "specific," related to the peculiar effects mediated by SARS-CoV2 (3). The mechanisms of myocardial damage are highlighted in Figure 1.

First, COVID-19 has general deleterious effects on the cardiovascular system, which were already described in other infections (i.e., influenza and community-acquired pneumoniae). 
TABLE 1 | Reduction in hospitalizations due to HF during COVID-19 pandemic period, compared with same period in the previous year or a different period in the same year (before COVID-19).

\begin{tabular}{|c|c|c|c|c|}
\hline Study (year) & $\begin{array}{l}\text { Number of } \\
\text { patients }\end{array}$ & Country & Study and control periods & $\begin{array}{l}\text { Reduction in HF } \\
\text { hospitalizations }\end{array}$ \\
\hline Bromage et al. (9) & 104 & England and Wales & $\begin{array}{l}2 \text { March-19 April } 2020 \text { vs. control period in } 2020 \\
\text { (pre-COVID) and the same periods in 2017-2019 }\end{array}$ & $-66 \%, p<0.01$ \\
\hline Cox et al. (10) & - & $\begin{array}{l}\text { Vanderbilt University } \\
\text { Medical Center, Nashville, } \\
\text { Tennessee }\end{array}$ & 22 March-20 April 2020 vs. same period in 2019 & $-62 \pm 7 \%, p<0.01$ \\
\hline Hall et al. (11) & - & USA & $\begin{array}{l}\text { Mean weekly hospitalization from January } 2020 \text { to } \\
11 \text { April. The significant and progressive decline } \\
\text { described in } 2020 \text { was not observed in } 2019 \text {, } \\
\text { excluding potential confounding based on } \\
\text { seasonal trends. }\end{array}$ & $\begin{array}{l}-50 \% \text { (after the first } \\
\text { case of COVID-19) }\end{array}$ \\
\hline Cannatà et al. (12) & 1,372 & South London & 7 January-14 June 2020 vs. same period in 2019 & $-40 \%, p<0.001$ \\
\hline Konig et al. (13) & 13,484 & Germany & $\begin{array}{l}13 \text { March-21 May } 2020 \text { vs. control periods in } 2020 \\
\text { (1 January-12 March) and } 2019 \text { (13 } \\
\text { March-21 May) }\end{array}$ & $-30 \%, p<0.01$ \\
\hline
\end{tabular}

COVID-19, Coronavirus Disease 2019; HF, heart failure.

Fever and sympathetic activation cause tachycardia with a consequent increase in myocardial oxygen consumption (2931). Moreover, prolonged bed rest and systemic inflammation favor coagulation disorders. Both venous and unusual arterial thromboembolic events were observed in COVID-19 patients $(32,33)$. Hypoxemia, another hallmark of COVID-19, is associated with enhanced oxidative stress with reactive oxygen species production and subsequent intracellular acidosis, mitochondrial damage, and cell death $(29,34)$.

A second series of indirect mechanisms are those related with the peculiar abnormal inflammatory response that COVID-19 may elicit: the presence of a proinflammatory surge, the so-called cytokine storm, may happen in a week after the infection and is thought to be central in the pathogenesis of the acute lung injury/ARDS spectrum, as it is reported in severely ill patients $(35,36)$. Indeed, during the acute phase of the infection, an imbalanced response of types 1 and $2 \mathrm{~T}$ helper cells may lead to a hyperinflammatory response $(35,36)$, resulting in an excessive release of cytokines: in particular, higher levels of interleukin-1 $\beta$ (IL-1 $\beta$ ), interleukin-6, interferon- $\gamma$, tumor necrosis factor (TNF), macrophage inflammatory protein, and vascular endothelial growth factor (VEGF) have been described in patients affected by severe COVID-19 (16-18), and are independently associated with a severe course of the infection and eventually death $(16,37)$. In addition, the hyperinflammation syndrome seems to be pivotal in the development of cardiac injury, since a positive correlation has been described between the increase in inflammatory markers and myocardial damage in COVID-19 (38-41). Consistently, previous in-vitro studies have shown that the release of proinflammatory cytokines such as TNF and IL$1 \beta$, in other septic conditions, were responsible for myocardial cells depression (42-44), through modulation of calcium channel activity and nitric oxide production $(43,44)$.

Cytokine storm may be as well the cause of acute HF: the inflammatory activation and oxidative stress are similarly present in $\mathrm{HF}$ and may predispose, combined with COVID-19, to a more severe clinical course (45-47). Finally, the marked inflammatory response takes place also in the endothelium, as demonstrated by post-mortem histological findings showing lymphocytic endotheliitis with apoptotic bodies and viral inclusion structures in multiple organs $(48,49)$. Endotheliitis can lead to disseminated intravascular coagulation with small or large vessels thrombosis and infarction and significant new vessel growth through a mechanism of intussusceptive angiogenesis $(49,50)$.

Consequently, anti-inflammatory therapies and thromboprophylaxis have been the mainly studied drugs for COVID-19 (51-54). Dexamethasone was found to be associated with lower 28-day mortality in the controlled, open-label Randomized Evaluation of COVID-19 Therapy (RECOVERY) trial (51). Beneficial effects were limited to those patients receiving ventilatory support (either invasive or noninvasive), while neutral effects were reported among patients not requiring oxygen therapy. The efficacy of steroids was confirmed in further retrospective series and in one meta-analysis of seven randomized trials, including 1,703 patients (53).

Finally, drugs that have been used as COVID-19 therapy may cause themselves myocardial injury. At the beginning of the pandemic, many drugs were proposed in an expedited manner (55). Hydroxychloroquine was initially proposed as an effective drug for the therapy of COVID-19. It is known that hydroxychloroquine has cardiovascular toxicity, as it may cause arrhythmias and heart failure (56). A recent meta-analysis, including a total of 5,652 COVID-19 patients, showed that treatment with hydroxychloroquine or chloroquine was associated with risk of drug-induced QT prolongation and higher incidence of torsades de pointes, ventricular tachycardia, or cardiac arrest (57), while no efficacy was found in the treatment of hospitalized patients with COVID-19 for hydroxychloroquine in the RECOVERY trial (58). Similarly, azithromycin was initially recommended in patients with COVID-19, but it may increase the risk of adverse CV events (high risk of QTC 
TABLE 2 | Prevalence, incidence, and mortality of pre-existing and acute HF in COVID-19.

\begin{tabular}{|c|c|c|c|c|c|c|}
\hline Study (year) & $\begin{array}{c}\text { Number of } \\
\text { patients }\end{array}$ & $\begin{array}{l}\text { Number of } \\
\text { patients } \\
\text { with history } \\
\text { of HF }\end{array}$ & $\begin{array}{l}\text { Prevalence of HF } \\
\text { history (\%) }\end{array}$ & $\begin{array}{l}\text { Main outcome of patients } \\
\text { with history of HF }\end{array}$ & $\begin{array}{l}\text { Incidence of } \\
\text { acute HF during } \\
\text { COVID-19 (\%) }\end{array}$ & $\begin{array}{l}\text { Outcome in acute HF } \\
\text { patients }\end{array}$ \\
\hline Inciardi et al. (21) & 99 & 21 & 21 & $\begin{array}{l}\text { Higher mortality in HF vs. } \\
\text { non-HF patients ( } 57 \text { vs. } \\
18 \%, p=0.009 \text { ) }\end{array}$ & - & - \\
\hline Shi et al. (24) & 671 & 22 & 3.3 & $\begin{array}{l}\text { History of HF was more } \\
\text { prevalent in dead patients } \\
\text { vs. survivors ( } 21 \text { vs. } 1.5 \%, p \\
<0.001 \text { ) }\end{array}$ & - & $\begin{array}{l}\text { Acute HF was the cause of } \\
\text { death in } 19.4 \% \text { of cases. }\end{array}$ \\
\hline Petrilli et al. (19) & 5,279 & 367 & 7 & $\begin{array}{l}\text { Adjusted HR for death } 1.77 \\
(95 \% \mathrm{Cl}, 1.43-2.2, p< \\
0.001)\end{array}$ & - & - \\
\hline Lala et al. (25) & 2,736 & 276 & 10.1 & $\begin{array}{l}\text { HR for death } 1.03(95 \% \mathrm{Cl} \\
0.77-1.37, p=0.867)\end{array}$ & - & - \\
\hline $\begin{array}{l}\text { Richardson et al. } \\
\text { (20) }\end{array}$ & 5,700 & 371 & 6.9 & - & - & - \\
\hline Rey et al. (26) & 3,080 & 152 & 4.9 & $\begin{array}{l}\text { Higher mortality in HF vs. } \\
\text { non-HF patients (48.7 vs. } \\
19 \%, p<0.001 \text { ) }\end{array}$ & 2.5 & $\begin{array}{l}\text { Acute HF patients had } \\
\text { higher mortality }(46.8 \text { vs. } \\
19.7 \%, p<0.001\end{array}$ \\
\hline Tomasoni et al. (27) & 692 & 90 & 13 & $\begin{array}{l}\text { Adjusted HR for death } 2.25 \\
(95 \% \mathrm{Cl}, 1.26-4.02, p= \\
0.006)\end{array}$ & 9.1 & $\begin{array}{l}\text { Acute HF patients had } \\
\text { higher mortality ( } 40.0 \text { vs. } \\
21.8 \%, p=0.004)\end{array}$ \\
\hline Zhou et al. (17) & 191 & - & - & - & 23 & $\begin{array}{l}\text { Acute HF was more } \\
\text { prevalent in dead patients } \\
\text { vs. survivors ( } 52 \text { vs. } 12 \%, p \\
<0.0001 \text { ) }\end{array}$ \\
\hline $\begin{array}{l}\text { Alvarez-Garcia et al. } \\
(28)\end{array}$ & 6,439 & 422 & 6.6 & $\begin{array}{l}\text { Adjusted OR for death } 1.88 \\
(1.27-2.78, p=0.002)\end{array}$ & 0.6 (de-novo HF) & $\begin{array}{l}\text { De-novo HF patients had } \\
\text { increased risk of ICU (HR, } \\
2.2 \text {; 95\% Cl, 1.2-3.8) and } \\
\text { intubation (HR, 2.2; } 95 \% \mathrm{Cl} \text {, } \\
\text { 1.2-4.3), but not mortality } \\
(\mathrm{HR}, 1.1,95 \% \mathrm{Cl}, 0.6-2.0)\end{array}$ \\
\hline
\end{tabular}

Cl, confidence interval; COVID-1, Coronavirus Disease 2019; HF, heart failure; HR, hazard ratio; OR, odds ratio.

prolongation, especially when administered concomitantly with hydroxychloroquine (59). Several antiviral drugs are known to cause mitochondrial dysfunction and cardiotoxicity $(60,61)$.

\section{Direct Mechanisms: the Role of ACE 2}

Angiotensin-converting enzyme (ACE) 2 is the key to understand the consequences of SARS-CoV-2 infection on the CV system. ACE2 is a membrane protein, that is highly expressed in different organs, including heart, lungs, gut, and kidneys. It mediates SARS-CoV-2 entry into the host cells (62). Thus, ACE2 may facilitate organ damage by direct virus entry, with different clinical implications, according to the target organ. The virus, once inside the cell, uses host's ribonucleic acid (RNA)-dependent RNA polymerase to replicate its own structural proteins and, when assembled, new virus is released from the cells; as a consequence, host cell can be damaged/destroyed in this process (5). Consistently, SARS-CoV-2 positivity in cardiac tissues could be documented in autoptic studies in consecutive patients who died as a consequence of COVID-19 (63). Supportively, in engineered heart tissue model of COVID-19 myocardial pathology, SARS-CoV-2 was found capable to directly infect cardiomyocytes through ACE2, resulting in contractile deficits, cytokine production, sarcomere disassembly, and cell death (64).

In addition, ACE2 may be not only a simple bystander in the pathophysiology of myocardial injury: indeed, besides being the receptor of SARS-CoV-2, is an enzyme involved in the renin-angiotensin-aldosterone system (RAAS). Once binding is complete, the virus attaches ACE2 throughout membrane fusion and invagination, causing a downregulation in the activity of ACE2 (65). Particularly, ACE2 cleaves angiotensin II into angiotensin 1-7, which has vasodilating and anti-inflammatory effects. ACE2 has also a weak affinity for angiotensin I and can convert it into the non-apeptide angiotensin 1-9, limiting angiotensin II synthesis by ACE, and with vasodilatatory effects through angiotensin type 2 (AT2) receptor stimulation. Thus, ACE2 can counteract the untoward effects of angiotensin II with vasodilatatory, antioxidant, and antifibrotic effects (66). Interestingly, ACE2 has also immunomodulatory properties both direct, through its interaction with macrophages, and indirect, reducing angiotensin II which stimulates inflammation (67). ACE2 downregulation by SARS-CoV-2 infection may 


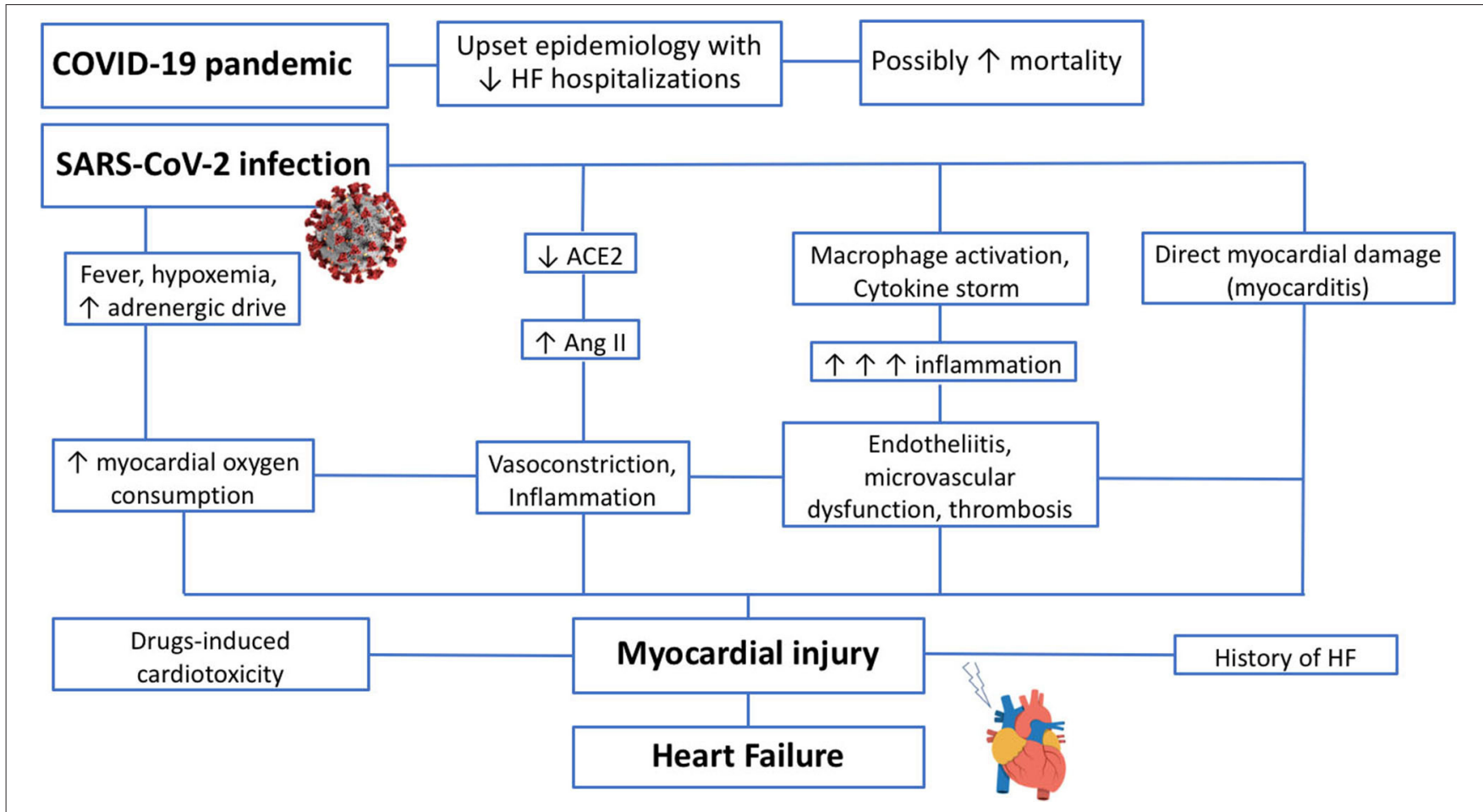

FIGURE 1 | COVID-19 and Heart Failure: mechanisms of myocardial damage in COVID-19. ACE2, angiotensin-converting enzyme2; Ang II, angiotensin II; COVID-19, coronavirus disease 2019; SARS-CoV-2, severe acute respiratory syndrome coronavirus 2; HF, heart failure.

increase angiotensin II levels, favoring AT1 receptor activity, with a subsequent vasoconstriction, fibrotic, proliferative, and proinflammatory effects (3).

\section{CLINICAL PRESENTATIONS OF MYOCARDIAL INJURY IN COVID-19}

COVID-19 often affects the heart. The clinical manifestations of cardiac involvement could range from an absolute lack of symptoms in the presence of increased troponin levels, with or without ECG or imaging abnormalities, to arrhythmia and sudden cardiac death, pulmonary embolism, acute coronary syndromes, myocarditis, acute HF, and cardiogenic shock $(3,68$, 69). The majority of patients with cardiac injury, as assessed by serum troponin elevation, do not have clear cardiac symptoms, whereas a minority is diagnosed with myocarditis or acute myocardial infarction. In more than a half of cases, ECG abnormalities compatible with myocardial ischemia (T-wave depression and inversion, ST segment depression, Q-waves) were described (38).

Recently, it has been shown that patients with cardiac injury have a greater prevalence of left ventricle (LV), right ventricle (RV), and pericardial abnormalities (69). Diastolic dysfunction was more frequent in patients with myocardial injury, possibly reflecting the higher prevalence of hypertension, diabetes, and chronic kidney disease among those patients, known risk factors for $\mathrm{HF}$ with preserved ejection fraction (HFpEF)
(70). Transthoracic echocardiography (TTE) abnormalities and concomitant cardiac injury were correlated with an increased risk of death; thus, TTE evaluation might be useful to characterize the underlying cardiac substrate, for risk stratification, and to guide clinical decisions (69).

\section{SUBCLINICAL ACUTE MYOCARDIAL INJURY IN COVID-19}

Since the first Chinese reports, a high incidence of cardiac injury, defined as the presence of elevated troponin (Tn) levels above the 99th percentile of the reference interval, was found in COVID-19 patients. The prevalence of cardiac injury ranges from $12 \%$ in unselected COVID-19 cases up to $41 \%$ in critically ill patients and patients with pre-existing cardiovascular diseases with a further rise to $75.8 \%$ in nonsurvivors (Table 3) (14, 17, 18, 24, 25, 38, 39, 71-82). The presence of elevated Tn levels is associated with abnormal laboratory findings (including white blood cells count, neutrophil and lymphocyte count, C-reactive protein, procalcitonin, $\mathrm{N}$ terminal pro-B-type natriuretic peptide, $\mathrm{D}$-dimer, transaminases, lactate dehydrogenase, total bilirubin, albumin, prothrombin time, and cytokines) (18) and a higher grade of pulmonary involvement in radiographic findings, suggesting an important multiorgan involvement $(21,38,73)$. This may be a consequence of the derangement in the innate and adaptive immune response, with a cytokine storm, similar to that previously observed in 
TABLE 3 | Cardiac injury prevalence and risk of in-hospital death in different geographical settings.

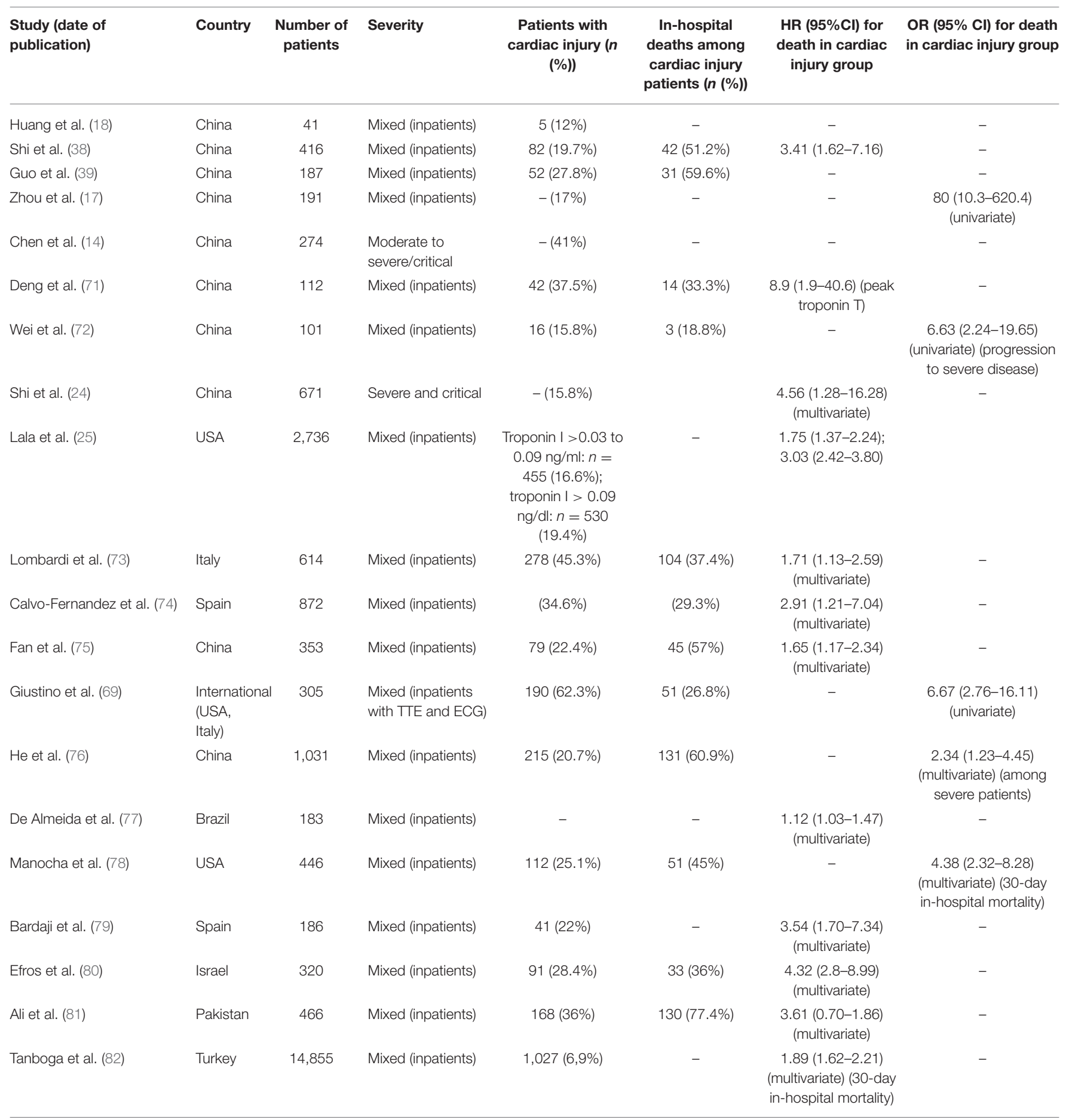

Cl, confidence interval; ECG, electrocardiogram; HF, heart failure; HR, hazard ratio; OR, odds ratio; TTE, transthoracic echocardiogram; USA, United States of America.

SARS and Middle East Respiratory Syndrome (MERS) (3). The presence of cardiac injury in COVID-19 is associated with more severe manifestations, complications, and adverse prognosis (14, $17,18,24,25,38,39,71-82)$. Data about the association between cardiac injury and mortality are summarized in Table 3.

Chinese reports firstly described the impact of comorbidities and underlying CVD on the development of myocardial injury and subsequent fatal outcomes $(15,39)$. In-hospital mortality was $7.6 \%$ for patients without underlying CVD and normal Tn levels, $13.3 \%$ for those with underlying CVD and normal Tn levels, $37.5 \%$ for those without underlying CVD but elevated Tn levels, and $69.4 \%$ for those with underlying CVD and elevated Tn (39). Moreover, the mortality rate increases with the magnitude of the troponin elevation: the mortality rate is higher among 
patients with vs. without cardiac injury [42 (51.2\%) vs. 15 (4.5\%); $p<0.001$ ] (39). After adjusting for multiple variables (e.g., age, pre-existing cardiovascular diseases, cerebrovascular diseases, diabetes mellitus, chronic obstructive pulmonary disease, renal failure, cancer, ARDS, creatinine levels, and NT-proBNP levels), the hazard ratio (HR) for death among patients with cardiac injury was 4.26 (95\% CI, 1.92-9.49), $p<0.01$ (39). The prognostic role of cardiac injury was confirmed in further and larger studies from different countries (including European, American, and Asiatic nations), with mortality HR ranging from 1.12 to 8.9 depending on the regression model used and OR up to 80 in a single univariate model $(17,71-82$ ) (Table 3). Data from a recent meta-analysis including 12,262 patients from 13 studies summarized that elevated Tn is associated with increased mortality (OR, 4.75; 95\% CI, 4.07-5.53; $p<0.001 ; I^{2}=19.9 \%$ ), with $55 \%$ sensitivity and $80 \%$ specificity (83). Therefore, Tn test offers an important prognostic tool for the stratification of the risk of mortality in patients affected by COVID-19.

\section{THE DILEMMA OF MYOCARDITIS IN COVID-19}

Sometimes, cardiac involvement is clinically evident, and besides elevation of serum Tn, patients complain of chest pain, palpitation, or symptoms of HF $(14,17,84)$. They may develop LV or biventricular dysfunction, in the absence of obstructive epicardial coronary disease, raising the clinical concern for myocarditis. Plenty of clinical reports described cases of acute myocarditis, presenting with cardiogenic shock, as a possible manifestation of COVID-19 (85-90).

However, myocarditis diagnosis can be controversial. Most of those cases were diagnosed based on cardiac magnetic resonance (CMR) findings that may show diffuse ventricular wall thickening and edema with wall pseudohypertrophy, with or without late gadolinium enhancement. Tissue diagnosis criteria were met only in few cases with endomyocardial biopsy (EMB) showing different degrees of aspecific myocardial inflammation and limited or absent myocardial necrosis (85, 86, 88, 90-92). Tissue findings in COVID-19 related to supposed myocarditis are enlisted in Table $4(5,48,85,86,88,92-106)$.

SARS-CoV-2 was shown within macrophages, but not in cardiomyocytes, in an earliest case report of clinically suspected acute myocarditis (88). Further studies documented viral invasion and necrosis of myocytes $(5,107)$. In a series of $104 \mathrm{EMB}$, performed in COVID-19 patients with suspected myocarditis or unexplained HF, SARS-CoV-2 was identified through RT-PCR only in five samples (102). In a multicentric post-mortem study, Basso et al. found that the most common cardiac autoptic evidence in patients dying for COVID-19 was aspecific interstitial macrophage infiltration (in $86 \%$ of cases), whereas $14 \%$ of the patients presented a multifocal lymphocytic myocarditis (92) (Table 4). A literature review, identifying 277 cardiac autopsies from 22 studies, showed that the prevalence of myocarditis in SARS-CoV-2-infected patients was 1.4\% (108). The most common histopathologic findings were myocardial hypertrophy (from 70 to $100 \%$ of cases) and myocardial fibrosis
(80-100\% of cases). Lymphocytic infiltrate and pericarditis were present in $<25 \%$ of cases, while common findings were endothelitis, macro- or microvascular thrombi, and macrophage infiltrate (86\% of cases) (108). Macrophage infiltration is an aspecific inflammatory histological finding, which can be found also in normal human hearts or in patients dying from bacterial sepsis and may be due to systemic hyperinflammatory response or other underlying disease rather than COVID-19 itself (109, 110).

Although a few cases of direct virus-related myocarditis may exist, the most common cardiac findings were nonmyocarditis inflammatory infiltrate and single cell ischemia, showing how multiple and complex mechanisms are responsible for myocardial injury in COVID-19 patients, as stated above $(67,111-113)$.

\section{CARDIOVASCULAR INVOLVEMENT AFTER COVID-19 VACCINATION}

COVID-19 vaccines are a critical tool for controlling the ongoing global pandemic. In large, randomized controlled trials, COVID19 vaccines were found to be safe and efficacious in preventing symptomatic, laboratory-confirmed, COVID-19. However, many adverse effects, namely, CV complications, have been described. Myocarditis may be a complication after mRNA COVID-19 vaccination (i.e., Pfizer-BioNTech and Moderna). Up to June 2021, more than a thousand cases of possible myocarditis and pericarditis have been signaled to the Vaccine Adverse Event Reporting System (VAERS) in the USA ${ }^{1}$. The cases are rare (hundreds of millions of doses have been administrated up to now) and were reported to be more common in young and adolescent males and after the second dose of the vaccine $^{1}$. Similarly, the European Medicines Agency (EMA) reports less than a thousand cases of myopericarditis up to June $2021^{2}$. The cases described in literature usually present with fever, chest pain, and dyspnea, together with changes on the electrocardiogram and cardiac magnetic resonance findings consistent with myocarditis; the symptoms usually resolved rapidly (114-120). The patients were treated with non-steroidal anti-inflammatory drugs (NSAIDs) only, but, in some cases, required intravenous immune globulin (IVIG) and corticosteroids (114-120). However, up-to-date, no causal relationship between vaccine administration and myocarditis has been established.

The Centers for Disease Control (CDC) continues to recommend COVID-19 vaccination for everyone 12 years of age and older ${ }^{1}$. Another possible but life-threatening complication of COVID-19 vaccination is vaccine-induced thrombotic thrombocytopenia (VITT) (also referred to as vaccine-induced prothrombotic immune thrombocytopenia or thrombosis with thrombocytopenia syndrome); VITT is characterized by thrombosis, often in unusual sites (specifically, cerebral venous sinus thrombosis or thrombosis in the portal, splanchnic, or

\footnotetext{
${ }^{1}$ https://www.cdc.gov/coronavirus/2019-ncov/vaccines/safety/myocarditis.html. ${ }^{2}$ https://www.ema.europa.eu/en/news/covid-19-vaccines- update-ongoingevaluation-myocarditis-pericarditis.
} 
TABLE 4 | Studies reporting cardiac tissue findings in COVID-19 patients.

\begin{tabular}{|c|c|c|c|}
\hline Study (year) & $\begin{array}{l}\text { Number of } \\
\text { patients }\end{array}$ & Design & Findings \\
\hline Basso et al. (92) & 21 & $\begin{array}{l}\text { Multicenter pathology study, } \\
\text { post-mortem }\end{array}$ & $\begin{array}{l}\text { Increased interstitial macrophage infiltration was present in } 86 \% \text { of the cases, whereas } \\
\text { lymphocytic myocarditis was present in } 14 \% \text { of the cases }\end{array}$ \\
\hline Varga et al. (48) & 3 & Case reports, post-mortem & Lymphocytic endotheliitis in lung, heart, kidney, and liver but no sign of lymphocytic myocarditis. \\
\hline Menter et al. (93) & 21 & Multicenter, post-mortem & $\begin{array}{l}\text { Myocardial hypertrophy ( } 71 \% \text { of cases), senile amyloidosis ( } 29 \% \text { of cases), peracute } \\
\text { myocardial necrosis ( } 14 \% \text { cases), acute myocardial infarction ( } 5 \% \text { cases) }\end{array}$ \\
\hline Lax et al. (94) & 11 & $\begin{array}{l}\text { Single-center, prospective } \\
\text { study, post-mortem }\end{array}$ & $\begin{array}{l}\text { Myocardial hypertrophy (100\%), coronary small vessel disease (54\%), myocardial fibrosis } \\
(91 \%), \text { focal lymphocytic infiltrate }(9 \%)\end{array}$ \\
\hline Buja et al. (95) & 3 & Multicenter, post-mortem & Lymphocytic myocarditis was reported in 1 case. \\
\hline Duarte-Neto et al. (96) & 10 & $\begin{array}{l}\text { Single-center, case series, } \\
\text { post-mortem }\end{array}$ & $\begin{array}{l}\text { Cardiomyocyte hypertrophy }(90 \%) \text {, myocardial fibrosis (90\%), previous myocardial infarction } \\
(40 \%) \text {, interstitial oedema (90\%) myocarditis (20\%), and fibrin thrombi }(20 \%)\end{array}$ \\
\hline Bradley et al. (97) & 14 & $\begin{array}{l}\text { Multicenter, case series, } \\
\text { post-mortem }\end{array}$ & $\begin{array}{l}\text { Cardiac findings were mostly non-specific: fibrosis (100\%) and myocyte hypertrophy (93\%). } \\
\text { Myocarditis was present with aggregates of lymphocytes surrounding necrotic myocytes in } 7 \%\end{array}$ \\
\hline Rapkiewicz et al. (98) & 7 & $\begin{array}{l}\text { Single-center, case series, } \\
\text { post-mortem }\end{array}$ & $\begin{array}{l}1 \text { case had focal acute lymphocyte-predominant inflammation in the myocardium. Otherwise, } \\
\text { cardiac histopathological changes were limited to minimal epicardial inflammation }(n=1) \text {, early } \\
\text { ischemic injury }(n=3) \text {, and mural fibrin thrombi }(n=2)\end{array}$ \\
\hline Grosse et al. (99) & 14 & $\begin{array}{l}\text { Single-center, case series, } \\
\text { post-mortem }\end{array}$ & $\begin{array}{l}\text { Myocardial hypertrophy (92.9\%), acute myocardial infarction ( } 21.4 \%) \text {, focal myocardial fibrosis } \\
(42.9 \%) \text {, amyloidosis }(7.1 \%), \text { mononuclear inflammatory cells in the myocardial interstitium } \\
(100 \%)\end{array}$ \\
\hline Hanley et al. (100) & 10 & $\begin{array}{l}\text { Multicenter, case series, } \\
\text { post-mortem }\end{array}$ & $\begin{array}{l}\text { Acute coronary thrombosis (10\%), thrombi in the microcirculation (56\%), aright atrial thrombus } \\
(11 \%) . \text { Pericarditis (22\%); marantic endocarditis in } 11 \%\end{array}$ \\
\hline Oprinca et al. (101) & 3 & $\begin{array}{l}\text { Single-center, case series, } \\
\text { post-mortem }\end{array}$ & $\begin{array}{l}\text { Mild to moderate perivascular edema, vascular congestion, small number of scattered } \\
\text { lymphocytes between the myocardial fibers }\end{array}$ \\
\hline Sala et al. (86) & 1 & Case report with EMB & $\begin{array}{l}\text { Diffuse T-lymphocytic inflammatory infiltrates with huge interstitial oedema and limited foci of } \\
\text { necrosis. No replacement fibrosis }\end{array}$ \\
\hline Tavazzi et al. (88) & 1 & Case report with EMB & $\begin{array}{l}\text { Low-grade interstitial and endocardial inflammation, with macrophages containing virions of } \\
\text { coronaviruses. Cardiac myocytes showed non-specific features consisting of focal myofibrillar } \\
\text { lysis and lipid droplets. }\end{array}$ \\
\hline Escher et al. (102) & 104 & Multicenter, EMB study & $\begin{array}{l}5 \text { EMBs were positive for SARS-CoV-2 E-gene-specific sequences. Other findings were active } \\
\text { myocarditis (13.4\%), inflammatory cardiomyopathy (32.6\%), borderline myocarditis ( } 2.9 \%) \text {; } \\
\text { dilated cardiomyopathy (41.3\%), and amyloidosis ( } 9.6 \%)\end{array}$ \\
\hline Lindner et al. (63) & 39 & Cohort study, post-mortem & $\begin{array}{l}\text { Viral presence within the myocardium could be documented in } 41 \% \text { but was not associated } \\
\text { with an influx of inflammatory cells }\end{array}$ \\
\hline Kawakami et al. (103) & 15 & $\begin{array}{l}\text { Literature review, } \\
\text { post-mortem }\end{array}$ & $\begin{array}{l}\text { None of the cases met the criteria of myocarditis, although in } 3 \text { cases microvascular infarction } \\
\text { was described. In } 2 \text { cases, the virus was detected by RT-PCR in the atria, but no inflammation } \\
\text { was described. }\end{array}$ \\
\hline Haslbauer et al. (104) & 23 & Multicenter, post-mortem & $\begin{array}{l}60 \% \text { of cases had myocardial RT-PCR positivity by SARS-CoV-2 PCR. Significantly higher } \\
\text { levels of capillary fibrin deposition, capillary dilatation, and parenchymal microhemorrhages } \\
\text { (consistent with microvascular dysfunction) compared with } 10 \text { autopsies without SARS-CoV- } 2 \text {. } \\
\text { Five cases presented with increased cardioinflammatory infiltrate presented but without } \\
\text { cardiomyocyte necrosis. Only while } 1 \text { case presented with active lymphohistiocytic myocarditis. }\end{array}$ \\
\hline Bearse et al. (105) & 41 & $\begin{array}{l}\text { Single-center, consecutive } \\
\text { cases, post-mortem }\end{array}$ & $\begin{array}{l}\text { Cardiac infection by SARS-CoV-2 (assessed by RT-PCR) was present in 30/41 cases. Cardiac } \\
\text { infection by SARS-CoV-2 is associated with more cardiac inflammation (monocytes and } \\
\text { macrophages). Four cases met criteria for myocarditis. }\end{array}$ \\
\hline Fox et al. (106) & 10 & $\begin{array}{l}\text { Single-center, case series, } \\
\text { post-mortem }\end{array}$ & $\begin{array}{l}\text { No evidence of lymphocytic myocarditis. In the COVID-19-affected cases, diffuse number of } \\
\text { infiltrative cells of monocytes/macrophage lineage was noticed, with upper quantiles as } \\
\text { compared to both matched control hearts. }\end{array}$ \\
\hline
\end{tabular}

EMB, endomyocardial biopsy; SARS-CoV-2, severe acute respiratory syndrome coronavirus 2; RT-PCR, reverse transcriptase-polymerase chain reaction.

hepatic veins), and concomitant thrombocytopenia (121). The cases reported were noticed after adenovirus-based vaccination (i.e., AstraZeneca or Johnson \& Johnson/Janssen) in patients without prior exposure to heparin (122-124). The majority of patients in these cases were women younger than 50 years of age, some of whom were receiving estrogen-replacement therapy or oral contraceptives (122-125). The pathogenesis is similar to heparin-induced thrombocytopenia (HIT): the enzyme-linked immunosorbent assay test in these cases identified antibodies directed against the platelet factor 4 (PF4)-heparin complex which activate platelets, similar to HIT antibodies (121-125). Patients usually presented with a median platelet counts at diagnosis of $20,000-30,000 / \mathrm{mm}^{3}$ with concomitant high levels of D-dimer and low levels of fibrinogen; almost $40 \%$ of the 
patients died, some from ischemic brain injury or superimposed hemorrhage (122-125). In the case of cerebral venous sinus thrombosis (CVST), patients usually presented with headache and progressive lethargy. The consensus treatment is based on the administration of intravenous immunoglobulin or corticosteroids (126).

The estimated incidence of CVST is 3.6 per million people after the AstraZeneca COVID-19 vaccine and 0.9 per million people after Johnson and Johnson vaccine (which is much lower than the rate of CVST in COVID-19, estimated at 207 per million) (127). According to the EMA, the risk of death and serious outcomes of COVID-19 (including thrombosis) outweighs the risk of VITT $^{3}$.

\section{HEART FAILURE AS A CONSEQUENCE OF COVID-19}

Acute HF was found to be a possible consequence of COVID19, with a dramatic impact on mortality (26). During COVID-19 hospitalization, about one-third of patients with previous HF had an acute decompensation of HF (27); however, acute HF can be developed not only as a decompensation of chronic HF but also as a new-onset HF (128) (Table 2). In an Italian multicenter study, acute HF occurred in $9.1 \%$ of patients during hospitalization for COVID-19, and almost half of them were "de-novo" HF in patients with no HF history (27). Among 3,080 consecutive patients with confirmed COVID-19 infection hospitalized in a tertiary center in Madrid (Spain), 2.5\% of patients were diagnosed with acute HF and suffered from significantly higher mortality as compared with patients without $\operatorname{HF}(46.8$ vs. $19.7 \%$; $p<0.001)$ (128). Arrhythmias during hospital admission and chronic HF were the main predictors of acute HF; however, $77.9 \%$ of acute HF did not have a previous history of HF (128).

In COVID-19 patients presenting acute HF, LV systolic function is not usually compromised; on the contrary, impairment of right ventricular (RV) systolic function and LV diastolic function can be found (129). Out of 100 patients hospitalized for COVID-19, 32\% were reported to have normal echocardiography, whereas $39 \%$ presented RV dilatation and dysfunction and $16 \% \mathrm{LV}$ diastolic dysfunction, whereas reduced LV EF was reported only in $<10 \%$ (130). Similar results are described in other small series $(131,132)$ and in a large international cohort study (69). Accordingly, LV diastolic impairment with elevated LV filling pressures (E/e' ratio) could be observed in a quarter of patients admitted for COVID-19 (132). Consistently, patients hospitalized with COVID-19 showed high likelihood of presence of HF with preserved ejection fraction (HFpEF) as compared with patients without COVID-19 according to the score of the Heart Failure Association (HFA) of the European Society of Cardiology (ESC), and HFpEF was found associated with cardiac structural and functional alterations and myocardial injury (133). Moreover, the longitudinal function could be impaired earlier than LVEF: in a Danish prospective multicenter cohort study, no differences were

${ }^{3}$ https://www.ema.europa.eu/en/news/covid-19-vaccine-astrazeneca-benefitsstill-outweigh-risks-despite-possible-link-rare-blood-clots. found between cases and controls from the general population regarding LVEF; on the contrary, LV global longitudinal strain (GLS) was significantly reduced (134). Speckle tracking was found to be able to identify a reduced basal LV longitudinal strain in more than a half of hospitalized COVID-19 patients (135, 136). Moreover, RV systolic function [assessed by RV longitudinal strain and tricuspid annular plane systolic excursion (TAPSE)] can be impaired in COVID-19 patients (137). A more pronounced reduction of mean values of LV-GLS and RV longitudinal strain could be found in severe COVID-19 patients, and speckle tracking analysis could predict mortality even after adjusting for multiple confounders $(130,137,138)$.

\section{LONG TERM CONSEQUENCES OF COVID-19 ON THE HEART}

Concerning data are emerging regarding the possibility of long-term subacute myocarditis following the recovery from SARS-CoV-2 infection and the development of HF as a longterm consequence of COVID-19 inflammatory cardiomyopathy. Follow-up clinical studies are starting to report the longterm COVID-19 consequences with many people still suffering from fatigue, dyspnea, and palpitations 3-6 months after the recovery from acute infection (139-142). In this context, imaging tests taken months after recovery from COVID-19 have shown ongoing signs of damage to the heart, even in people who experienced only mild COVID-19 symptoms. A German study suggested that 2 months after SARS-CoV-2 positivity, $78 \%$ of survivors had persistent heart involvement, of which $60 \%$ presented ongoing signs of myocarditis, revealed with cardiac magnetic resonance (CMR) (142). In a study including competitive athletes, referred to the sports medicine clinic after testing positive for COVID-19, 15\% of patients had CMR findings suggestive of ongoing myocarditis and $30.8 \%$ suggestive of prior myocardial injury (143). In another CMR multicenter study evaluating 148 patients during convalescence, 2 months after severe COVID-19 infection with troponin elevation, myocarditis-like injury can be encountered in almost a half of cases (144). A large CMR cohort study among 1,597 US competitive athletes from the Big Ten Universities recently affected by SARS-CoV-2, reported 37 athletes with clinical and subclinical myocarditis (145). Echocardiographic assessment of patients with recent COVID-19 may, as well, show abnormalities in terms of higher degrees of diastolic dysfunction, lower men values of LV GLS, and presence of pericardial effusion, consistent with CMR findings, up to 2 months after COVID-19 recovery (146-148).

The meaning of those imaging findings are currently unknown; however, persistent myocardial damage and fibrosis in the subacute and chronic phases after recovery suggest that COVID-19 may be an independent risk factor for the development of HF (70). The early identification of patients with cardiac abnormalities is of pivotal importance as they may benefit from cardioprotective therapy and need different followup strategies. 


\section{CONCLUSIONS}

COVID-19 and HF have a strong connection that go beyond pathophysiology. First of all, COVID-19 pandemic had an impact on HF hospitalization: a reduction on hospital admission for $\mathrm{HF}$ has been extensively described, and this may have an impact on HF mortality. Second, history of HF is a frequent comorbidity in patients hospitalized for COVID-19. It is associated with a higher mortality and more complications during the clinical course, and this association is independent from other variables related with HF and COVID-19 severity.

Third, we have shown the high prevalence of cardiac injury following COVID-19 which is often diagnosed only through biomarker measurements. However, besides

\section{REFERENCES}

1. Coronaviridae study Group of the International Committee on Taxonomy of Viruses. The species Severe acute respiratory syndrome-related coronavirus: classifying 2019-nCoV and naming it SARS-CoV-2. Nat Microbiol. (2020) 5:536-44. doi: 10.1038/s41564-020-0695-z

2. WHO. Coronavirus Disease (COVID-19) Dashboard. Available online at: https://covid19.who.int (accessed June 1, 2021).

3. Tomasoni D, Italia L, Adamo M, Inciardi RM, Lombardi CM, Solomon SD, et al. COVID-19 and heart failure: from infection to inflammation and angiotensin II stimulation. Searching for evidence from a new disease. Eur J Heart Fail. (2020) 22:957-66. doi: 10.1002/ejhf.1871

4. Zheng YY, Ma YT, Zhang JY, Xie X. COVID-19 and the cardiovascular system. Nat Rev Cardiol. (2020) 17:259-60. doi: 10.1038/s41569-020-0360-5

5. Liu PP, Blet A, Smyth D, Li H. The science underlying COVID-19: implications for the cardiovascular system. Circulation. (2020) 142:6878. doi: 10.1161/CIRCULATIONAHA.120.047549

6. Xiong TY, Redwood S, Prendergast B, Chen M. Coronaviruses and the cardiovascular system: acute and long-term implications. Eur Heart J. (2020) 41:1798-800. doi: 10.1093/eurheartj/ehaa231

7. Solomon MD, McNulty EJ, Rana JS, Leong TK, Lee C, Sung SH, et al. The Covid-19 pandemic and the incidence of acute myocardial infarction. $N$ Engl J Med. (2020) 383:691-3. doi: 10.1056/NEJMc2015630

8. Tomasoni D, Adamo M, Italia L, Branca L, Chizzola G, Fiorina C, et al. Impact of COVID-2019 outbreak on prevalence, clinical presentation and outcomes of ST-elevation myocardial infarction. J Cardiovasc Med. (2020) 21:874-81. doi: 10.2459/JCM.0000000000001098

9. Bromage DI, Cannatà A, Rind IA, Gregorio C, Piper S, Shah AM, et al. The impact of COVID-19 on heart failure hospitalization and management: report from a Heart Failure Unit in London during the peak of the pandemic. Eur J Heart Fail. (2020) 22:978-84. doi: 10.1002/ejhf.1925

10. Cox ZL, Lai P, Lindenfeld J. Decreases in acute heart failure hospitalizations during COVID-19. Eur J Heart Fail. (2020) 22:1045-6. doi: 10.1002/ejhf.1921

11. Hall ME, Vaduganathan M, Khan MS, Papadimitriou L, Long RC, Hernandez GA, et al. Reductions in heart failure hospitalizations during the COVID-19 pandemic. J Card Fail. (2020) 26:462-3. doi: 10.1016/j.cardfail.2020.05.005

12. Cannatà A, Bromage DI, Rind IA, Gregorio C, Bannister C, Albarjas M, et al. Temporal trends in decompensated heart failure and outcomes during COVID-19: a multisite report from heart failure referral centres in London. Eur J Heart Fail. (2020) 22:2219-24. doi: 10.1002/ejhf.1986

13. König S, Hohenstein S, Meier-Hellmann A, Kuhlen R, Hindricks G, Bollmann A; Helios Hospitals, Germany. In-hospital care in acute heart failure during the COVID-19 pandemic: insights from the Germanwide Helios hospital network. Eur J Heart Fail. (2020) 22:2190201. doi: 10.1002/ejhf.2044

14. Chen $\mathrm{T}, \mathrm{Wu} \mathrm{D}$, Chen $\mathrm{H}$, Yan $\mathrm{W}$, Yang D, Chen $\mathrm{G}$, et al. Clinical characteristics of 113 deceased patients with coronavirus disease subclinical myocardial damage, SARS-CoV-2 infection can cause myocarditis with a severe reduction of LVEF, or diastolic dysfunction in a larger number of patients. Finally, HF may be a short- or long-term consequence of COVID-19 inflammatory cardiomyopathy with a dramatic consequence on the prognosis.

\section{AUTHOR CONTRIBUTIONS}

LI contributed to the design and conception of the manuscript and wrote the first draft. SB, LS, and EP wrote sections of the manuscript. DT reviewed and edited the manuscript. MM and MA supervised and edited the manuscript. All authors contributed to the article and approved the submitted version.
2019: retrospective study. BMJ. (2020) 368:m1091. doi: 10.1136/bmj.m 1091

15. Wang D, Hu B, Hu C, Zhu F, Liu X, Zhang J, et al. Clinical characteristics of 138 hospitalized patients with 2019 novel coronavirus-infected pneumonia in Wuhan, China. JAMA. (2020) 323:1061-69. doi: 10.1001/jama.2020.1585

16. Yang X, Yu Y, Xu J, Shu H, Xia J, Liu H, et al. Clinical course and outcomes of critically ill patients with SARS-CoV-2 pneumonia in Wuhan, China: a single-centered, retrospective, observational study. Lancet Respir Med. (2020) 8:475-81. doi: 10.1016/S2213-2600(20)30079-5

17. Zhou F, Yu T, Du R, Fan G, Liu Y, Liu Z, et al. Clinical course and risk factors for mortality of adult inpatients with COVID-19 in Wuhan, China: a retrospective cohort study. Lancet. (2020) 395:105462. doi: 10.1016/S0140-6736(20)30566-3

18. Huang C, Wang Y, Li X, Ren L, Zhao J, Hu Y, et al. Clinical features of patients infected with 2019 novel coronavirus in Wuhan, China. Lancet. (2020) 395:497-506. doi: 10.1016/S0140-6736(20)30183-5

19. Petrilli CM, Jones SA, Yang J, Rajagopalan H, O’Donnell L, Chernyak Y, et al. Factors associated with hospital admission and critical illness among 5279 people with coronavirus disease 2019 in New York City: prospective cohort study. BMJ. (2020) 369:m1966. doi: 10.1136/bmj.m1966

20. Richardson S, Hirsch JS, Narasimhan M, Crawford JM, McGinn T, Davidson KW, et al. Presenting characteristics, comorbidities, and outcomes among 5700 patients hospitalized with COVID-19 in the New York City Area. JAMA. (2020) 323:2052-9. doi: 10.1001/jama.2020.6775

21. Inciardi RM, Adamo M, Lupi L, Cani DS, Di Pasquale M, Tomasoni D, et al. Characteristics and outcomes of patients hospitalized for COVID19 and cardiac disease in Northern Italy. Eur Heart J. (2020) 41:18219. doi: 10.1093/eurheartj/ehaa388

22. Wu Z, McGoogan JM. Characteristics of and important lessons from the coronavirus disease 2019 (COVID-19) outbreak in China: summary of a report of 72314 cases from the Chinese center for disease control and prevention. JAMA. (2020) 323:1239-42. doi: 10.1001/jama.2020.2648

23. Bae S, Kim SR, Kim M, Shim WJ, Park SM. Impact of cardiovascular disease and risk factors on fatal outcomes in patients with COVID-19 according to age: a systematic review and meta-analysis. Heart. (2021) 107:373-80. doi: 10.1136/heartjnl-2020-317901

24. Shi S, Qin M, Cai Y, Liu T, Shen B, Yang F, et al. Characteristics and clinical significance of myocardial injury in patients with severe coronavirus disease 2019. Eur Heart J. (2020) 41:2070-9. doi: 10.1093/eurheartj/ehaa408

25. Lala A, Johnson KW, Januzzi JL, Russak AJ, Paranjpe I, Richter $\mathrm{F}$, et al. Prevalence and impact of myocardial injury in patients hospitalized with COVID-19 infection. J Am Coll Cardiol. (2020) 76:53346. doi: 10.1101/2020.04.20.20072702

26. Rey JR, Caro-Codón J, Rosillo SO, Iniesta ÁM, Castrejón-Castrejón S, Marco-Clement I et al. Heart failure in COVID-19 patients: prevalence, incidence and prognostic implications. Eur J Heart Fail. (2020) 22:220515. doi: 10.1002/ejhf.1990 
27. Tomasoni D, Inciardi RM, Lombardi CM, Tedino C, Agostoni P, Ameri P, et al. Impact of heart failure on the clinical course and outcomes of patients hospitalized for COVID-19. Results of the Cardio-COVID-Italy multicentre study. Eur J Heart Fail. (2020) 22:2238-47. doi: 10.1002/ejhf.2052

28. Alvarez-Garcia J, Lee S, Gupta A, Cagliostro M, Joshi AA, RivasLasarte $M$, et al. Prognostic impact of prior heart failure in patients hospitalized with COVID-19. J Am Coll Cardiol. (2020) 76:233448. doi: 10.1016/j.jacc.2020.09.549

29. Violi F, Cangemi R, Falcone M, Taliani G, Pieralli F, Vannucchi $\mathrm{V}$, et al. Cardiovascular complications and short-term mortality risk in community-acquired pneumonia. Clin Infect Dis. (2017) 64:148693. doi: $10.1093 /$ cid/cix 164

30. Madjid M, Miller CC, Zarubaev VV, Marinich IG, Kiselev OI, Lobzin YV, et al. Influenza epidemics and acute respiratory disease activity are associated with a surge in autopsy-confirmed coronary heart disease death: results from 8 years of autopsies in 34,892 subjects. Eur Heart J. (2007) 28:12050. doi: 10.1093/eurheartj/ehm035

31. Corrales-Medina VF, Alvarez KN, Weissfeld LA, Angus DC, Chirinos JA, Chang CC, et al. Association between hospitalization for pneumonia and subsequent risk of cardiovascular disease. JAMA. (2015) 313:26474. doi: 10.1001/jama.2014.18229

32. Klok FA, Kruip MJHA, van der Meer NJM, Arbous MS, Gommers DAMPJ, Kant KM, et al. Incidence of thrombotic complications in critically ill ICU patients with COVID-19. Thromb Res. (2020) 191:1457. doi: 10.1016/j.thromres.2020.04.013

33. de Roquetaillade C, Chousterman BG, Tomasoni D, Zeitouni M, Houdart E, Guedon A, et al. Unusual arterial thrombotic events in Covid-19 patients. Int J Cardiol. (2021) 323:281-4. doi: 10.1016/j.ijcard.2020.08.103

34. Takasu O, Gaut JP, Watanabe E, To K, Fagley RE, Sato B, et al. Mechanisms of cardiac and renal dysfunction in patients dying of sepsis. Am J Respir Crit Care Med. (2013) 187:509-17. doi: 10.1164/rccm.201211-1983OC

35. Ragab D, Salah Eldin H, Taeimah M, Khattab R, Salem R. The COVID19 cytokine storm; what we know so far. Front Immunol. (2020) 11:1446. doi: 10.3389/fimmu.2020.01446

36. Fajgenbaum DC, June CH. Cytokine storm. N Engl J Med. (2020) 383:225573. doi: 10.1056/NEJMra2026131

37. Del Valle DM, Kim-Schulze S, Huang H-H, Beckmann ND, Nirenberg S, Wang B, et al. An inflammatory cytokine signature predicts COVID-19 severity and survival. Nat Med. (2020) 26:1636-43. doi: 10.1038/s41591-020-1051-9

38. Shi S, Qin M, Shen B, Cai Y, Liu T, Yang F, et al. Association of cardiac injury with mortality in hospitalized patients with COVID-19 in Wuhan, China. JAMA Cardiol. (2020) 5:802-10. doi: 10.1001/jamacardio.2020.0950

39. Guo $\mathrm{T}$, Fan $\mathrm{Y}$, Chen $\mathrm{M}$, Wu $\mathrm{X}$, Zhang $\mathrm{L}, \mathrm{He} \mathrm{T}$, et al. Cardiovascular implications of fatal outcomes of patients with coronavirus disease 2019 (COVID-19). JAMA Cardiol. (2020) 5:811-8. doi: 10.1001/jamacardio.2020.1017

40. Mehta P, McAuley DF, Brown M, Sanchez E, Tattersall RS, Manson JJ. et al. COVID-19: consider cytokine storm syndromes and immunosuppression. Lancet. (2020) 395:1033-4. doi: 10.1016/S0140-6736(20)30628-0

41. Arévalos V, Ortega-Paz L, Rodríguez-Arias JJ, Calvo M, Castrillo L, Salazar A, et al. Myocardial injury in COVID-19 patients: association with inflammation, coagulopathy and in-hospital prognosis. J Clin Med. (2021) 10:2096. doi: 10.3390/jcm 10102096

42. Kumar A, Thota V, Dee L, Olson J, Uretz E, Parrillo JE. Tumor necrosis factor alpha and interleukin lbeta are responsible for in vitro myocardial cell depression induced by human septic shock serum. J Exp Med. (1996) 183:949-58. doi: 10.1084/jem.183.3.949

43. Kumar A, Brar R, Wang P, Dee L, Skorupa G, Khadour F, et al. Role of nitric oxide and cGMP in human septic serum-induced depression of cardiac myocyte contractility. Am J Physiol. (1999) 276:R26576. doi: 10.1152/ajpregu.1999.276.1.R265

44. Joulin O, Petillot P, Labalette M, Lancel S, Neviere R. Cytokine profile of human septic shock serum inducing cardiomyocyte contractile dysfunction. Physiol Res. (2007) 56:291-7.

45. Unudurthi SD, Luthra P, Bose RJC, McCarthy JR, Kontaridis MI. Cardiac inflammation in COVID-19: lessons from heart failure. Life Sci. (2020) 260:118482. doi: 10.1016/j.lfs.2020.118482
46. Markousis-Mavrogenis G, Tromp J, Ouwerkerk W, Devalaraja M, Anker SD, Cleland JG, et al. The clinical significance of interleukin-6 in heart failure: results from the BIOSTAT-CHF study. Eur J Heart Fail. (2019) 21:965-73. doi: 10.1002/ejhf.1482

47. van der Pol A, van Gilst WH, Voors AA, van der Meer P. Treating oxidative stress in heart failure: past, present and future. Eur J Heart Fail. (2019) 21:425-35. doi: 10.1002/ejhf.1320

48. Varga Z, Flammer AJ, Steiger P, Haberecker M, Andermatt R, Zinkernagel AS, et al. Endothelial cell infection and endotheliitis in COVID-19. Lancet. (2020) 395:1417-8. doi: 10.1016/S0140-6736(20)30937-5

49. Ackermann M, Verleden SE, Kuehnel M, Haverich A, Welte T, Laenger F, et al. Pulmonary vascular endothelialitis, thrombosis, and angiogenesis in Covid-19. N Engl J Med. (2020) 383:120-8. doi: 10.1056/NEJMoa2015432

50. Gavriilaki E, Anyfanti P, Gavriilaki M, Lazaridis A, Douma S, Gkaliagkousi E. Endothelial dysfunction in COVID-19: lessons learned from coronaviruses. Curr Hypertens Rep. (2020) 22:63. doi: 10.1007/s11906-020-01078-6

51. RECOVERY Collaborative Group, Horby P, Lim WS, Emberson JR, Mafham M, Bell JL, et al. Dexamethasone in hospitalized patients with Covid-19. N Engl J Med. (2021) 384:693-704. doi: 10.1056/NEJMoa2021436

52. Feldmann M, Maini RN, Woody JN, Holgate ST, Winter G, Rowland M, et al. Trials of anti-tumour necrosis factor therapy for COVID-19 are urgently needed. Lancet. (2020) 395:1407-9. doi: 10.1016/S0140-6736(20)30858-8

53. WHO Rapid Evidence Appraisal for COVID-19 Therapies (REACT) Working Group, Sterne JAC, Murthy S, Diaz JV, Slutsky AS, Villar J, et al. Association between administration of systemic corticosteroids and mortality among critically ill patients with COVID-19: a meta-analysis. JAMA. (2020) 324:1330-41. doi: 10.1001/jama.2020.17023

54. Ameri P, Inciardi RM, Di Pasquale M, Agostoni P, Bellasi A, Camporotondo $\mathrm{R}$, et al. Pulmonary embolism in patients with COVID-19: characteristics and outcomes in the Cardio-COVID Italy multicenter study. Clin Res Cardiol. (2021) 110:1020-8. doi: 10.1007/s00392-020-01766-y

55. Kupferschmidt K, Cohen J. Race to find COVID-19 treatments accelerates. Science. (2020) 367:1412-3. doi: 10.1126/science.367.6485.1412

56. Chatre C, Roubille F, Vernhet H, Jorgensen C, Pers YM. Cardiac complications attributed to chloroquine and hydroxychloroquine: a systematic review of the literature. Drug Saf. (2018) 41:91931. doi: 10.1007/s40264-018-0689-4

57. Tleyjeh IM, Kashour Z, AlDosary O, Riaz M, Tlayjeh H, Garbati $\mathrm{MA}$, et al. Cardiac toxicity of chloroquine or hydroxychloroquine in patients with COVID-19: a systematic review and metaregression analysis. Mayo Clin Proc Innov Qual Outcomes. (2021) 5:137-50. doi: 10.1016/j.mayocpiqo.2020.10.005

58. RECOVERY Collaborative Group, Horby P, Mafham M, Linsell L, Bell JL, Staplin N, et al. Effect of hydroxychloroquine in hospitalized patients with covid-19. N Engl J Med. (2020) 383:2030-40. doi: 10.1056/NEJMoa20 22926

59. Nguyen LS, Dolladille C, Drici MD, Fenioux C, Alexandre J, Mira JP, et al. Cardiovascular toxicities associated with hydroxychloroquine and azithromycin: an analysis of the world health organization pharmacovigilance database. Circulation. (2020) 142:303-5. doi: 10.1161/CIRCULATIONAHA.120.048238

60. Varga ZV, Ferdinandy P, Liaudet L, Pacher P. Drug-induced mitochondrial dysfunction and cardiotoxicity. Am J Physiol Heart Circ Physiol. (2015) 309:H1453-67. doi: 10.1152/ajpheart.00554.2015

61. Frattini S, Maccagni G, Italia L, Metra M, Danzi GB. Coronavirus disease 2019 and cardiovascular implications. J Cardiovasc Med (Hagerstown). (2020) 21:725-32. doi: 10.2459/JCM.0000000000001068

62. Wrapp D, Wang N, Corbett KS, Goldsmith JA, Hsieh CL, Abiona O, et al. Cryo-EM structure of the $2019-\mathrm{nCoV}$ spike in the prefusion conformation. Science. (2020) 367:1260-3. doi: 10.1126/science.abb2507

63. Lindner D, Fitzek A, Bräuninger H, Aleshcheva G, Edler $\mathrm{C}$, Meissner $\mathrm{K}$, et al. Association of cardiac infection with SARS-CoV-2 in confirmed COVID-19 autopsy cases. JAMA Cardiol. (2020) 5:1281-5. doi: 10.1001/jamacardio.2020. 3551

64. Bailey AL, Dmytrenko O, Greenberg L, Bredemeyer AL, Ma P, Liu J, et al. SARS-CoV-2 infects human engineered heart tissues and models COVID-19 myocarditis. JACC 
Basic Transl Sci. (2021) 6:331-45. doi: 10.1016/j.jacbts.2021.0 1.002

65. Yan R, Zhang Y, Li Y, Xia L, Guo Y, Zhou Q. Structural basis for the recognition of SARS-CoV-2 by full-length human ACE2. Science. (2020) 367:1444-8. doi: 10.1126/science.abb2762

66. Patel VB, Zhong JC, Grant MB, Oudit GY. Role of the ACE2/angiotensin 1-7 axis of the renin-angiotensin system in heart failure. Circ Res. (2016) 118:1313-26. doi: 10.1161/CIRCRESAHA.116.307708

67. Madjid M, Safavi-Naeini P, Solomon SD, Vardeny O. Potential effects of coronaviruses on the cardiovascular system: a review. JAMA Cardiol. (2020) 5:831-40. doi: 10.1001/jamacardio.2020.1286

68. Kochi AN, Tagliari AP, Forleo GB, Fassini GM, Tondo C. Cardiac and arrhythmic complications in patients with COVID-19. J Cardiovasc Electrophysiol. (2020) 31:1003-8. doi: 10.1111/jce.14479

69. Giustino G, Croft LB, Stefanini GG, Bragato R, Silbiger JJ, Vicenzi M, et al. Characterization of myocardial injury in patients with COVID-19. J Am Coll Cardiol. (2020) 76:2043-55. doi: 10.1016/j.jacc.2020.08.069

70. Zaccone G, Tomasoni D, Italia L, Lombardi CM, Metra M. Myocardial involvement in COVID-19: an interaction between comorbidities and heart failure with preserved ejection fraction. A further indication of the role of inflammation. Curr Heart Fail Rep. (2021) 18:99106. doi: 10.1007/s11897-021-00509-y

71. Deng Q, Hu B, Zhang Y, Wang H, Zhou X, Hu W, et al. Suspected myocardial injury in patients with COVID-19: evidence from front-line clinical observation in Wuhan, China. Int J Cardiol. (2020) 311:11621. doi: 10.1016/j.ijcard.2020.03.087

72. Wei JF, Huang FY, Xiong TY, Liu Q, Chen H, Wang H, et al. Acute myocardial injury is common in patients with COVID-19 and impairs their prognosis. Heart. (2020) 106:1154-9. doi: 10.1136/heartjnl-2020-317007

73. Lombardi CM, Carubelli V, Iorio A, Inciardi RM, Bellasi A, Canale C, et al. Association of troponin levels with mortality in italian patients hospitalized with coronavirus disease 2019: results of a multicenter study. JAMA Cardiol. (2020) 5:1274-80. doi: 10.1001/jamacardio.2020.3538

74. Calvo-Fernández A, Izquierdo A, Subirana I, Farré N, Vila J, Durán X, Markers of myocardial injury in the prediction of short-term COVID-19 prognosis. Rev Esp Cardiol. (2021) 74:576-83. doi: 10.1016/j.rec.2020.09.011

75. Fan Q, Zhu H, Zhao J, Zhuang L, Zhang H, Xie H, et al. Risk factors for myocardial injury in patients with coronavirus disease 2019 in China. ESC Heart Fail. (2020) 7:4108-17. doi: 10.1002/ehf2.13022

76. He X, Wang L, Wang H, Xie Y, Yu Y, Sun J, et al. Factors associated with acute cardiac injury and their effects on mortality in patients with COVID-19. Sci Rep. (2020) 10:20452. doi: 10.1038/s41598-020-77172-1

77. Almeida Junior GLG, Braga F, Jorge JK, Nobre GF, Kalichsztein M, Faria PMP, et al. Prognostic value of troponin-T and B-type natriuretic peptide in patients hospitalized for COVID-19. Arq Bras Cardiol. (2020) 115:660-6. English, Portuguese. doi: 10.36660/abc.20200385

78. Manocha KK, Kirzner J, Ying X, Yeo I, Peltzer B, Ang B, et al. Troponin and other biomarker levels and outcomes among patients hospitalized with COVID-19: derivation and validation of the HA2T2 COVID-19 mortality risk score. J Am Heart Assoc. (2021) 10:e018477. doi: 10.1161/JAHA.120.018477

79. Bardají A, Carrasquer A, Sánchez-Giménez R, Lal-Trehan N, Del-MoralRonda V, Peiró ÓM, et al. Prognostic implications of myocardial injury in patients with and without COVID-19 infection treated in a university hospital. Rev Esp Cardiol. (2021) 74:24-32. doi: 10.1016/j.rec.2020.08.027

80. Efros O, Barda N, Meisel E, Leibowitz A, Fardman A, Rahav G, et al. Myocardial injury in hospitalized patients with COVID19 infection-Risk factors and outcomes. PLOS ONE. (2021) 16:e247800. doi: 10.1371/journal.pone.0247800

81. Ali J, Khan FR, Ullah R, Hassan Z, Khattak S, Lakhta G, et al. Cardiac troponin $\mathrm{i}$ levels in hospitalized COVID-19 patients as a predictor of severity and outcome: a retrospective cohort study. Cureus. 13:e14061. doi: 10.7759/cureus.14061

82. Tanboga IH, Canpolat U, Özcan Çetin EH, Kundi H, Turan S, Celik O, et al. The prognostic role of cardiac troponin in hospitalized COVID-19 patients. Atherosclerosis. (2021) 325:83-8. doi: 10.1016/j.atherosclerosis.2021.04.006

83. Wibowo A, Pranata R, Akbar MR, Purnomowati A, Martha JW. Prognostic performance of troponin in COVID-19: a diagnostic meta-analysis and meta-regression. Int $J$ Infect Dis. (2021) 105:312-8. doi: 10.1016/j.ijid.2021.02.113

84. Dong N, Cai J, Zhou Y, Liu J, Li F. End-stage heart failure with COVID-19: strong evidence of myocardial injury by 2019-nCoV. JACC Heart Fail. (2020) 8:515-7. doi: 10.1016/j.jchf.2020.04.001

85. Inciardi RM, Lupi L, Zaccone G, Italia L, Raffo M, Tomasoni D, et al. Cardiac involvement in a patient with coronavirus disease 2019 (COVID-19). JAMA Cardiol. (2020) 5:819-24. doi: 10.1001/jamacardio.2020.1096

86. Sala S, Peretto G, Gramegna M, Palmisano A, Villatore A, Vignale D, et al. Acute myocarditis presenting as a reverse Tako-Tsubo syndrome in a patient with SARS-CoV-2 respiratory infection. Eur Heart J. (2020) 41:18612. doi: 10.1093/eurheartj/ehaa286

87. Doyen D, Moceri P, Ducreux D, Dellamonica J. Myocarditis in a patient with COVID-19: a cause of raised troponin and ECG changes. Lancet. (2020) 395:1516. doi: 10.1016/S0140-6736(20)30912-0

88. Tavazzi G, Pellegrini C, Maurelli M, Belliato M, Sciutti F, Bottazzi A, et al. Myocardial localization of coronavirus in COVID-19 cardiogenic shock. Eur J Heart Fail. (2020) 22:911-5. doi: 10.1002/ejhf.1828

89. Zeng JH, Liu YX, Yuan J, Wang FX, Wu WB, Li JX, et al. First case of COVID19 complicated with fulminant myocarditis: a case report and insights. Infection. (2020) 48:773-7. doi: 10.1007/s15010-020-01424-5

90. Kim IC, Kim JY, Kim HA, Han S. COVID-19-related myocarditis in a 21-year-old female patient. Eur Heart J. (2020) 41:1859. doi: 10.1093/eurheartj/ehaa288

91. Xu Z, Shi L, Wang Y, Zhang J, Huang L, Zhang C, et al. Pathological findings of COVID-19 associated with acute respiratory distress syndrome. Lancet Respir Med. (2020) 8:420-2. doi: 10.1016/S2213-2600(20)30076-X

92. Basso C, Leone O, Rizzo S, De Gaspari M, van der Wal AC, Aubry MC, et al. Pathological features of COVID-19-associated myocardial injury: a multicentre cardiovascular pathology study. Eur Heart J. (2020) 41:382735. doi: 10.1093/eurheartj/ehaa664

93. Menter T, Haslbauer JD, Nienhold R, Savic S, Hopfer H, Deigendesch N, et al. Postmortem examination of COVID-19 patients reveals diffuse alveolar damage with severe capillary congestion and variegated findings in lungs and other organs suggesting vascular dysfunction. Histopathology. (2020) 77:198-209. doi: 10.1111/his.14134

94. Lax SF, Skok K, Zechner P, Kessler HH, Kaufmann N, Koelblinger C, et al. Pulmonary arterial thrombosis in COVID-19 with fatal outcome: results from a prospective, single-center, clinicopathologic case series. Ann Intern Med. (2020) 173:350-61. doi: 10.7326/M20-2566

95. Buja LM, Wolf DA, Zhao B, Akkanti B, McDonald M, Lelenwa L, et al. The emerging spectrum of cardiopulmonary pathology of the coronavirus disease 2019 (COVID-19): report of 3 autopsies from Houston, Texas, and review of autopsy findings from other United States cities. Cardiovasc Pathol. (2020) 48:107233. doi: 10.1016/j.carpath.2020.107233

96. Duarte-Neto AN, Monteiro RAA, da Silva LFF, Malheiros DMAC, de Oliveira EP, Theodoro-Filho J, et al. Pulmonary and systemic involvement in COVID-19 patients assessed with ultrasound-guided minimally invasive autopsy. Histopathology. (2020) 77:186-97. doi: 10.1111/his.14160

97. Bradley BT, Maioli H, Johnston R, Chaudhry I, Fink SL, Xu H, et al. Histopathology and ultrastructural findings of fatal COVID-19 infections in Washington State: a case series. Lancet. (2020) 396:32032. doi: 10.1016/S0140-6736(20)31305-2

98. Rapkiewicz AV, Mai X, Carsons SE, Pittaluga S, Kleiner DE, Berger JS, et al. Megakaryocytes and platelet-fibrin thrombi characterize multi-organ thrombosis at autopsy in COVID-19: a case series. EClinicalMedicine. (2020) 24:100434. doi: 10.1016/j.eclinm.2020.100434

99. Grosse C, Grosse A, Salzer HJF, Dünser MW, Motz R, Langer R. Analysis of cardiopulmonary findings in COVID-19 fatalities: high incidence of pulmonary artery thrombi and acute suppurative bronchopneumonia. Cardiovasc Pathol. (2020) 49:107263. doi: 10.1016/j.carpath.2020.1 07263

100. Hanley B, Naresh KN, Roufosse C, Nicholson AG, Weir J, Cooke GS, et al. Histopathological findings and viral tropism in UK patients with severe fatal COVID-19: a post-mortem study. Lancet Microbe. (2020) 1:e24553. doi: 10.1016/S2666-5247(20)30115-4

101. Oprinca GC, Muja LA. Postmortem examination of three SARS-CoV-2-positive autopsies including histopathologic and 
immunohistochemical analysis. Int J Legal Med. (2021) 135:32939. doi: 10.1007/s00414-020-02406-w

102. Escher F, Pietsch H, Aleshcheva G, Bock T, Baumeier C, Elsaesser A, et al. Detection of viral SARS-CoV-2 genomes and histopathological changes in endomyocardial biopsies. ESC Heart Fail. (2020) 7:24407. doi: $10.1002 /$ ehf2.12805

103. Kawakami R, Sakamoto A, Kawai K, Gianatti A, Pellegrini D, Nasr A, et al. Pathological evidence for SARS-CoV-2 as a cause of myocarditis: JACC review topic of the week. J Am Coll Cardiol. (2021) 77:31425. doi: 10.1016/j.jacc.2020.11.031

104. Haslbauer JD, Tzankov A, Mertz KD, Schwab N, Nienhold R, Twerenbold $\mathrm{R}$, et al. Characterisation of cardiac pathology in 23 autopsies of lethal COVID-19. J Pathol Clin Res. (2021) 7:326-37. doi: 10.1002/cjp2.212

105. Bearse M, Hung YP, Krauson AJ, Bonanno L, Boyraz B, Harris CK, et al. Factors associated with myocardial SARS-CoV-2 infection, myocarditis, and cardiac inflammation in patients with COVID-19. Mod Pathol. (2021) 34:1345-57. doi: 10.1038/s41379-021-00790-1

106. Fox SE, Falgout L, Vander Heide RS. COVID-19 myocarditis: quantitative analysis of the inflammatory infiltrate and a proposed mechanism. Cardiovasc Pathol. (2021) 107361. doi: 10.1016/j.carpath.2021.107361. [Epub ahead of print].

107. Dolhnikoff M, Ferreira Ferranti J, de Almeida Monteiro RA, DuarteNeto AN, Soares Gomes-Gouvêa M, Viu Degaspare N, et al. SARSCoV-2 in cardiac tissue of a child with COVID-19-related multisystem inflammatory syndrome. Lancet Child Adolesc Health. (2020) 4:7904. doi: $10.1016 / \mathrm{S} 2352-4642(20) 30257-1$

108. Halushka MK, Vander Heide RS. Myocarditis is rare in COVID-19 autopsies: cardiovascular findings across 277 postmortem examinations. Cardiovasc Pathol. (2021) 50:107300. doi: 10.1016/j.carpath.2020.1 07300

109. Azzawi M, Hasleton PS, Kan SW, Hillier VF, Quigley A, Hutchinson IV. Distribution of myocardial macrophages in the normal human heart. J Anat. (1997) 191:417-23. doi: 10.1046/j.1469-7580.1997.1913 0417.x

110. Rossi MA, Celes MR, Prado CM, Saggioro FP. Myocardial structural changes in long-term human severe sepsis/septic shock may be responsible for cardiac dysfunction. Shock. (2007) 27:10-8. doi: 10.1097/01.shk.0000235141.05528.47

111. Clerkin KJ, Fried JA, Raikhelkar J, Sayer G, Griffin JM, Masoumi A, et al. COVID-19 and cardiovascular disease. Circulation. (2020) 141:1648655. doi: 10.1161/CIRCULATIONAHA.120.046941

112. Zhou R. Does SARS-CoV-2 cause viral myocarditis in COVID-19 patients? Eur Heart J. (2020) 41:2123. doi: 10.1093/eurheartj/ehaa392

113. Peretto G, Sala S, Caforio ALP. Acute myocardial injury, MINOCA, or myocarditis? Improving characterization of coronavirus-associated myocardial involvement. Eur Heart J. (2020) 41:2124-5. doi: 10.1093/eurheartj/ehaa396

114. Marshall M, Ferguson ID, Lewis P, Jaggi P, Gagliardo C, Collins JS, et al. Symptomatic acute myocarditis in seven adolescents following Pfizer-BioNTech COVID- 19 vaccination. Pediatrics. (2021) e2021052478. doi: 10.1542/peds.2021-052478. [Epub ahead of print].

115. Mansour J, Short RG, Bhalla S, Woodard PK, Verma A, Robinson X, et al. Acute myocarditis after a second dose of the mRNA COVID19 vaccine: a report of two cases. Clin Imaging. (2021) 78:2479. doi: 10.1016/j.clinimag.2021.06.019

116. Muthukumar A, Narasimhan M, Li QZ, Mahimainathan L, Hitto I, Fuda $\mathrm{F}$, et al. In depth evaluation of a case of presumed myocarditis following the second dose of COVID-19 mRNA vaccine. Circulation. (2021). doi: 10.1161/CIRCULATIONAHA.121.056038. [Epub ahead of print].

117. Larson K, Ammirati E, Adler ED, Cooper LT, Hong KN, Saponara G, et al. Myocarditis after BNT162b2 and mRNA-1273 vaccination. Circulation. (2021). doi: 10.1161/CIRCULATIONAHA.121.055913. [Epub ahead of print].

118. Rosner CM, Genovese L, Tehrani BN, Atkins M, Bakhshi H, Chaudhri S, et al. Myocarditis temporally associated with COVID-19 vaccination. Circulation. (2021). doi: 10.1161/CIRCULATIONAHA.121.055891. [Epub ahead of print].
119. Albert E, Aurigemma G, Saucedo J, Gerson DS. Myocarditis following COVID-19 vaccination. Radiol Case Rep. (2021) 16:2142-5. doi: 10.1016/j.radcr.2021.05.033

120. Abu Mouch S, Roguin A, Hellou E, Ishai A, Shoshan U, Mahamid L, et al. Myocarditis following COVID-19 mRNA vaccination. Vaccine. (2021) 39:3790-3. doi: 10.1016/j.vaccine.2021.05.087

121. Cines DB, Bussel JB. SARS-CoV-2 vaccine-induced immune thrombotic thrombocytopenia. N Engl J Med. (2021) 384:22546. doi: 10.1056/NEJMe2106315

122. Greinacher A, Thiele T, Warkentin TE, Weisser K, Kyrle PA, Eichinger S. Thrombotic thrombocytopenia after ChAdOx1 nCov-19 vaccination. N Engl J Med. (2021) 384:2092-101. doi: 10.1056/NEJMoa2104840

123. Schultz NH, Sørvoll IH, Michelsen AE, Munthe LA, LundJohansen F, Ahlen MT, et al. Thrombosis and thrombocytopenia after ChAdOx1 nCoV-19 vaccination. $N$ Engl $J$ Med. (2021) 384:2124-30. doi: 10.1056/NEJMoa2104882

124. Muir KL, Kallam A, Koepsell SA, Gundabolu K. Thrombotic thrombocytopenia after Ad26.COV2.S vaccination. N Engl J Med. (2021) 384:1964-5. doi: 10.1056/NEJMc2105869

125. See I, Su JR, Lale A, Woo EJ, Guh AY, Shimabukuro TT, et al. US case reports of cerebral venous sinus thrombosis with thrombocytopenia after Ad26.COV2.S vaccination, March 2 to April 21, 2021. JAMA. (2021) 325:2448-56. doi: 10.1001/jama.2021.7517

126. American Heart Association/American Stroke Association Stroke Council Leadership. Diagnosis and management of cerebral venous sinus thrombosis with vaccine-induced thrombotic thrombocytopenia. Stroke. (2021) 57:2478-82. doi: 10.1161/STROKEAHA.121.035564

127. Bikdeli B, Chatterjee S, Arora S, Monreal M, Jimenez D, Krumholz HM, et al. Cerebral venous sinus thrombosis in the US population, after adenovirusbased SARS-CoV-2 vaccination, and After COVID-19. J Am Coll Cardiol. (2021) 78:408-11. doi: 10.1016/j.jacc.2021.06.001. [Epub ahead of print].

128. Alvarez-Garcia J, Jaladanki S, Rivas-Lasarte M, Cagliostro M, Gupta A, Joshi A, et al. New heart failure diagnoses among patients hospitalized for COVID19. J Am Coll Cardiol. (2021) 77:2260-2. doi: 10.1016/j.jacc.2021.03.006

129. Szekely Y, Lichter Y, Taieb P, Banai A, Hochstadt A, Merdler I, et al. Spectrum of cardiac manifestations in COVID19: a systematic echocardiographic study. Circulation. (2020) 142:342-53. doi: 10.1161/CIRCULATIONAHA.120.047971

130. Mahmoud-Elsayed HM, Moody WE, Bradlow WM, Khan-Kheil AM, Senior J, Hudsmith LE, et al. Echocardiographic findings in patients with COVID-19 pneumonia. Can J Cardiol. (2020) 36:1203-7. doi: 10.1016/j.cjca.2020.05.030

131. Schott JP, Mertens AN, Bloomingdale R, O'Connell TF, Gallagher MJ, Dixon S, et al. Transthoracic echocardiographic findings in patients admitted with SARS-CoV-2 infection. Echocardiography. (2020) 37:15516. doi: 10.1111/echo.14835

132. Goerlich E, Metkus TS, Gilotra NA, Wu KC, Cingolani OH, Hays AG. Prevalence and clinical correlates of echo-estimated right and left heart filling pressures in hospitalized patients with coronavirus disease 2019. Crit Care Explor. (2020) 2:e0227. doi: 10.1097/CCE.0000000000000227

133. Hadzibegovic S, Lena A, Churchill TW, Ho JE, Potthoff S, Denecke C, et al. Heart Failure with preserved ejection fraction according to the HFAPEFF score in COVID-19 patients: clinical correlates and echocardiographic findings. Eur J Heart Fail. (2021). doi: 10.1002/ejhf.2210. [Epub ahead of print].

134. Lassen MCH, Skaarup KG, Lind JN, Alhakak AS, Sengeløv M, Nielsen $\mathrm{AB}$, et al. Echocardiographic abnormalities and predictors of mortality in hospitalized COVID-19 patients: the ECHOVID-19 study. ESC Heart Fail. (2020) 7:4189-97. doi: 10.1002/ehf2.13044

135. Goerlich E, Gilotra NA, Minhas AS, Bavaro N, Hays AG, Cingolani OH. Prominent longitudinal strain reduction of basal left ventricular segments in patients with coronavirus disease-19. J Card Fail. (2021) 27:1004. doi: 10.1016/j.cardfail.2020.09.469

136. Stöbe S, Richter S, Seige M, Stehr S, Laufs U, Hagendorff A. Echocardiographic characteristics of patients with SARS-CoV-2 infection. Clin Res Cardiol. (2020) 109:1549-66. doi: 10.1007/s00392-020-01727-5

137. Baycan OF, Barman HA, Atici A, Tatlisu A, Bolen F, Ergen P, et al. Evaluation of biventricular function in patients with COVID-19 using 
speckle tracking echocardiography. Int J Cardiovasc Imaging. (2021) 37:13544. doi: 10.1007/s10554-020-01968-5

138. Li Y, Li H, Zhu S, Xie Y, Wang B, He L, et al. Prognostic value of right ventricular longitudinal strain in patients with COVID-19. JACC Cardiovasc Imaging. (2020) 13:2287-99. doi: 10.1016/j.jcmg.2020.04.014

139. Huang C, Huang L, Wang Y, Li X, Ren L, Gu X, et al. 6-month consequences of COVID-19 in patients discharged from hospital: a cohort study. Lancet Lond Engl. (2021) 397:220-32. doi: 10.1016/S0140-6736(20)32656-8

140. Townsend L, Dyer AH, Jones K, Dunne J, Mooney A, Gaffney F, et al. Persistent fatigue following SARS-CoV-2 infection is common and independent of severity of initial infection. PLoS ONE. (2020) 15:e0240784. doi: 10.1371/journal.pone.0240784

141. van den Borst B, Peters JB, Brink M, Schoon Y, Bleeker-Rovers CP, Schers $\mathrm{H}$, et al. Comprehensive health assessment three months after recovery from acute COVID-19. Clin Infect Dis Off Publ Infect Dis Soc Am. (2020) ciaa1750. doi: 10.1093/cid/ciaa1750. [Epub ahead of print].

142. Puntmann VO, Carerj ML, Wieters I, Fahim M, Arendt C, Hoffmann J, et al. Outcomes of cardiovascular magnetic resonance imaging in patients recently recovered from coronavirus disease 2019 (COVID-19). JAMA Cardiol. (2020) 5:1265-73. doi: 10.1001/jamacardio.2020.3557

143. Rajpal S, Tong MS, Borchers J, Zareba KM, Obarski TP, Simonetti $\mathrm{OP}$, et al. Cardiovascular magnetic resonance findings in competitive athletes recovering from COVID-19 infection. JAMA Cardiol. (2021) 6:116. doi: 10.1001/jamacardio.2020.4916

144. Kotecha T, Knight DS, Razvi Y, Kumar K, Vimalesvaran K, Thornton G. Patterns of myocardial injury in recovered troponin-positive COVID-19 patients assessed by cardiovascular magnetic resonance. Eur Heart J. (2021).

145. Daniels CJ, Rajpal S, Greenshields JT, Rosenthal GL, Chung EH, Terrin M, et al. Prevalence of clinical and subclinical myocarditis in competitive athletes with recent SARS-CoV-2 infection: results from the big ten COVID-19 cardiac registry. JAMA Cardiol. (2021) e212065. doi: 10.1001/jamacardio.2021.2065. [Epub ahead of print].
146. Brito D, Meester S, Yanamala N, Patel HB, Balcik BJ, Casaclang-Verzosa $\mathrm{G}$, et al. High prevalence of pericardial involvement in college student athletes recovering from COVID-19. JACC Cardiovasc Imaging. (2021) 14:541-55. doi: 10.1016/j.jcmg.2020.10.023

147. Özer S, Candan L, Özyildiz AG, Turan OE. Evaluation of left ventricular global functions with speckle tracking echocardiography in patients recovered from COVID-19. Int J Cardiovasc Imaging. (2021) 37:222733. doi: 10.1007/s10554-021-02211-5

148. Weckbach LT, Curta A, Bieber S, Kraechan A, Brado J, Hellmuth JC, et al. Myocardial inflammation and dysfunction in COVID-19-associated myocardial injury. Circ Cardiovasc Imaging. (2021) 14:e012220. doi: 10.1161/CIRCIMAGING.120.01 1713

Conflict of Interest: The authors declare that the research was conducted in the absence of any commercial or financial relationships that could be construed as a potential conflict of interest.

Publisher's Note: All claims expressed in this article are solely those of the authors and do not necessarily represent those of their affiliated organizations, or those of the publisher, the editors and the reviewers. Any product that may be evaluated in this article, or claim that may be made by its manufacturer, is not guaranteed or endorsed by the publisher.

Copyright (๑ 2021 Italia, Tomasoni, Bisegna, Pancaldi, Stretti, Adamo and Metra. This is an open-access article distributed under the terms of the Creative Commons Attribution License (CC BY). The use, distribution or reproduction in other forums is permitted, provided the original author(s) and the copyright owner(s) are credited and that the original publication in this journal is cited, in accordance with accepted academic practice. No use, distribution or reproduction is permitted which does not comply with these terms. 